\title{
To study the role of tranexamic acid in the management of menorrhagia
}

\author{
U. S. Hangarga ${ }^{1} *$, Rita D. ${ }^{2}$, Reshma Reddy Edula ${ }^{1}$
}

${ }^{1}$ Department of Obstetrics and Gynecology, Navodaya Medical College, Raichur, Karnataka, India
${ }^{2}$ Department of Obstetrics and Gynecology, SDM Medical College, Dharwad, Karnataka, India

Received: 07 October 2016

Revised: 17 October 2016

Accepted: 20 October 2016

\author{
*Correspondence: \\ Dr. Rita D., \\ E-mail: rita.vijayachandra@gmail.com
}

Copyright: (c) the author(s), publisher and licensee Medip Academy. This is an open-access article distributed under the terms of the Creative Commons Attribution Non-Commercial License, which permits unrestricted non-commercial use, distribution, and reproduction in any medium, provided the original work is properly cited.

\begin{abstract}
Background: Heavy menstrual bleeding is a significant case of morbidity during the reproductive years. Approximately $30 \%$ of women complain of menorrhagia and it is the main presenting problem of women consulting a gynaecologist. In addition, excessive menstrual bleeding accounts for about two-thirds of all hysterectomies. This amount of blood loss can cause disturbance of the woman's social, occupational or sexual life, as well as medical risks such as chronic iron deficiency anemia. Objective of the study was to determine if tranexenic acid can effectively and safely reduce menstrual blood loss in menorrhagia.

Methods: 100 cases selected for the study who complained of regular long/ heavy menstrual bleeding more than 7 days or blood loss more than $80 \mathrm{ml}$, who are at the age of $20-45$ years. This study includes measurement of menstrual blood loss, duration of bleeding, number of sanitary pad usage for two menstrual cycles who complained of regular excessive menstrual bleeding using pictogram and taken history of IUCD insertion. Abdominal, gyanecological examination and ultra sound has been done to rule out any pelvic pathology. Drug Tranexamic acid 500mg QID were given to the patients who had mean menstrual blood loss of more than $80 \mathrm{ml}$ based on assessment in the previous two menstrual cycles.

Results: The total study shows the effect of drugs on the amount of bleeding is $41.6 \%$ (P-value $<0.05$ ), there is significant reduction is seen in number of sanitary pad usage from 5.44 to 3.96 ( $\mathrm{P}$ - value <0.05) and there is significant reduction in duration of bleeding. There are minimal gastrointestinal side effects, and there is $32 \%$ discontinuation of treatment in our study as patient is not satisfied.

Conclusions: Treatment with tranexamic acid could potentially improve quality of life of women. It is also effective treatment for menorrhagia caused by IUCD. Current clinical evidence concludes that size and type of fibroid has significant influence on effect of treatment. Tranexamic acid has been doc umented and found to have no effect on uterus with adenomyosis and endometrial polyp.
\end{abstract}

Keywords: Haemoglobin, Tranexamic acid, Menorrhagia, Hypertension

\section{INTRODUCTION}

Heavy menstrual bleeding (HMB) has a significant impact on quality life of a women. ${ }^{1}$ Menorrhagia can be defined subjectively as "Abnormally long or heavy menses, lasting $>7$ days or involving blood loss $>80 \mathrm{ml}$.", Objectively it is a total menstrual blood loss greater than or equal to $80 \mathrm{ml}$ per period. ${ }^{3}$ Excessive menstrual bleeding is a significant cause of morbidity during the reproductive years. Approximately $30 \%$ of women complain of menorrhagia and it is the main presenting problem of women consulting a gynaecologist. ${ }^{4}$ In addition, excessive menstrual bleeding accounts for about two-thirds of all hysterectomies and a large proportion of endoscopic endometrial destructive surgery, therefore using substantial health-care resources. ${ }^{5}$ This amount of 
blood loss can cause disturbance of the woman's social, occupational or sexual life, and give rise to concern about possible underlying serious disease (in particular cancer), as well as medical risks such as chronic iron deficiency anemia.

Heavy periods can be debilitating, can lead to social embarrassment and medical problems, symptoms such as fatigue, exhaustion, shortness of breath, and anemia. Depending on the type of treatment or cause, women with menorrhagia office visits can range from 2-6 times a year. What is known/unknown about the condition is that the most common causes include anovulation and abnormal growths in the uterus (polyps or fibroids), having condition that increases bleeding. Some symptoms and effects of menorrhagia is the constant need to change pads $>3 \mathrm{hrs}$ or use $>21$ pads during a period. ${ }^{6}$ Menorrhagia also leads to Iron Deficiency Anemia (IDA). Treatment depends on cause of bleeding, preferences of the woman, and the desire for children. The usual methods that are used to treat the condition are Pharmacological management including Hormonal birth control, hormonal IUD, Implant, Depo-Provera, Antifibrionlytics, NSAIDS, Progestin, GnRH agonists. If pharmacological management do not control symptoms, surgery is an option. Surgeries include endometrial ablation and hysterectomies. A significantly elevated Fibrinolytic activity in the endometrium caused by a premenstrual rise in tissue Plasminogen activators is believed to be an underlying mechanism for Menorrhagia. ${ }^{7}$ Plasminogen activator Inhibitors (anti fibrinolytic agents) have therefore been promoted as a treatment for menorrhagia. ${ }^{8}$ Tranexamic Acid (TA) is one such non-hormonal antifibrinolytic agent that enhances blood clotting. Hence the present study was aimed to evaluate the efficacy and safer use of Tranexamic acid in decreasing the symptoms of menorrhagia and observe its untoward side effects among patients attending Navodaya medical college, Raichur.

The objective of the study was to determine if tranexenic acid can effectively and safely reduce menstrual blood loss in menorrhagia.

\section{METHODS}

This study was carried out in the institute of Navodaya Medical College Hospital and Research Center from January 2014 to December 2015.

For this purpose 100 cases selected for the study who complained of regular long or heavy menstrual bleeding lasting $>7$ days or involving blood loss $>80 \mathrm{ml}$.

\section{Selection of cases}

\section{Inclusion criteria}

- Patient of 20-45 years complaining of regular heavy menstrual bleeding.

\section{Exclusion criteria}

Excluded patients are with history of,

- Hypertension

- Renal or hepatic impairment

- $\quad$ Previous thromboembolic disease

- Inflammatory bowel disease

- Peptic or intestinal ulceration

- Coagulation or fibrinolytic disease

- Malignancies

Detailed history was taken from the patients regarding presenting complaints, history of IUCD insertion, onset of excessive bleeding and past menstrual history.

A thorough general examination was done for the presence of pallor, thyroid enlargement, breast pathology and spine. Heart and lungs are auscultated for any additional sounds. Blood pressure was recorded.

A per abdominal examination and gynaecological examination was done including per speculum and bimanual examination to rule out any pelvic pathology.

\section{Investigations}

- $\mathrm{Hb}$

- PCV

- Peripheral smear

- Coagulation profile

- Platelet count

- $\quad$ Blood grouping and Rh typing

- Pap smear

- Endometrial sampling beyond 35 years of age patients

- USG

Before prescribing tranexamic acid, menstrual blood loss assessment was done for two menstrual cycles using pictorial blood assessment chart (PBAC).

\section{Follow up}

At each follow up visit amount of bleeding, number of bleeding days, numbers of sanitary pads were assessed using pictorial blood assessment chart. Adverse effects if any were recorded. Effect on dysmenorrhoea, patient satisfaction and well-being were asked.

At the end of the study patient satisfaction was assessed by asking "would you like to continue with this treatment?" If the patient answered "no" the reason were recorded.

Efficacy of drug was analyzed before and after treatment with tranexamic acid. 


\section{RESULTS}

Tab Tranexamic acid 500mg TID to QID was given to this patient who has objectively measured blood loss of more than $80 \mathrm{ml}$ per cycle in a total 100 cases.

Table 1: Based on the age the IUCD menorrhagia and other causes of menorrhagia age group.

\begin{tabular}{|c|c|c|c|c|}
\hline \multirow[b]{2}{*}{$\begin{array}{l}\text { Age in } \\
\text { years }\end{array}$} & \multicolumn{2}{|c|}{ No of cases } & \multirow[b]{2}{*}{$\begin{array}{l}\text { Total } \\
\text { cases }\end{array}$} & \multirow[b]{2}{*}{ Percentage } \\
\hline & $\begin{array}{l}\text { IUCD } \\
\text { Menor- } \\
\text { rhagia }\end{array}$ & $\begin{array}{l}\text { Menor- } \\
\text { rhagia }\end{array}$ & & \\
\hline 20 to 25 & 19 & & 19 & $19 \%$ \\
\hline 26 to 35 & 5 & 32 & 37 & $37 \%$ \\
\hline 36 to 45 & - & 44 & 44 & $44 \%$ \\
\hline
\end{tabular}

Above table shows that majority of IUCD induced menorrhagia cases are within 25 years age group as in this group, IUCD users are more and other causes of menorrhagia cases are in age group of 35 to 45 years age indicating its prevalence more in perimenopausal age group.

Table 2: Based on parity.

\begin{tabular}{|lllll|}
\hline Parity & $\begin{array}{l}\text { No of cases } \\
\text { IUCD } \\
\text { Menor } \\
\text { rhagia }\end{array}$ & $\begin{array}{l}\text { Menor } \\
\text { rhagia }\end{array}$ & $\begin{array}{l}\text { Total } \\
\text { cases }\end{array}$ & Percentage \\
\hline Nulli para & - & 2 & 2 & $2 \%$ \\
\hline Para 1 & 22 & - & 22 & $22 \%$ \\
\hline Para 2 & 2 & 16 & 18 & $18 \%$ \\
\hline Multi para & - & 58 & 58 & $58 \%$ \\
\hline
\end{tabular}

This table shows that majority of IUCD induced menorrhagia cases are primi para and majority of multipara are due to other causes of menorrhagia and two are nullipara.

Table 3: Ultra sound findings.

\begin{tabular}{|lll|}
\hline Organs & Findings & No of cases \\
\hline \multirow{3}{*}{ Uterus } & Normal size & 57 \\
\cline { 2 - 3 } & Bulky uterus & 23 \\
\cline { 2 - 3 } & Fibroid & 18 \\
\cline { 2 - 3 } & Endonetrial polyp & 2 \\
\hline \multirow{2}{*}{ Adnexa } & Normal & 94 \\
\hline \multirow{2}{*}{$\begin{array}{l}\text { Endometrial } \\
\text { thickness }\end{array}$} & Cystic & 6 \\
\hline
\end{tabular}

Most of the cases are with in normal range of BMI. (Body mass index is equal to weight in $\mathrm{kgs} / \mathrm{height} 2$ in meters. 4 cases are obese $(>30$ BMI). The menstrual disturbances in the obese women may be due to hormonal disturbances.
Clinically, normal uterus found in $57 \%$ of cases. $23 \%$ of cases showed bulky uterus (6-8 weeks) in which other causes for uterine enlargement like adenomyosis were included. Fibroid found in $18 \%$.

No adnexal pathology was detected in $94 \%$ of cases and only $6 \%$ had cystic ovaries. $47 \%$ had $1-5 \mathrm{~mm}$ endometrial thickness, $49 \%$ had 6-9mm endometrial thickness, $4 \%$ had $>9 \mathrm{~mm}$ endometrial thickness. In these cases, endometrial hyperplasia and carcinoma were ruled out by $\mathrm{D}$ and $\mathrm{C}$.

Only in age group of 35 to 45 years D and C was done to know the type of endometrium and to rule out hyperplasia and carcinoma. Out of 54 cases 48 cases have secretory type of endometrium, 5 had proliferative endometrium, 1 had hyperplasia. From this it is clear that most of the regular cycles are ovulatory.

Table 4: Haemoglobin.

\begin{tabular}{|lll|}
\hline Hemoglobin in gm \% & No of cases & Percentage \\
\hline$<6$ & 3 & $3 \%$ \\
\hline $6-7.5$ & 8 & $8 \%$ \\
\hline $7.5-9$ & 39 & $39 \%$ \\
\hline $9-10.5$ & 34 & $34 \%$ \\
\hline$>10.5$ & 16 & $16 \%$ \\
\hline
\end{tabular}

Most of patients had haemoglobin concentration between 7.5 to $10.5 \mathrm{gm} \% .3$ patients had haemoglobin less than $6 \mathrm{gm} \%$ that were given blood transfusion. The factors contributing to anemia are excessive menstrual blood loss and nutritional deficiencies.

Table 5: Mean haemoglobin concentration before and after management.

\begin{tabular}{|llll|}
\hline Hemoglobin \% & Mean & SD & p-value \\
\hline Before treatment & 8.5 & 0.8 & $<0.05$ \\
\hline After treatment & 9.6 & 1.3 & Significant \\
\hline
\end{tabular}

Table 6: Effect of drug on menstrual blood loss.

\begin{tabular}{|llll|}
\hline $\begin{array}{l}\text { Effect on } \\
\text { menstrual blood } \\
\text { loss }\end{array}$ & $\begin{array}{l}\text { No of } \\
\text { cases }\end{array}$ & Percentage & p-value \\
\hline Decreased & 72 & $72 \%$ & $<0.05$ \\
\hline No change & 28 & $28 \%$ & Significant \\
\hline
\end{tabular}

It is clear that menstrual blood loss decreased in $68 \%$ of cases, remained same in $32 \%$ after taking the drug. The cases that had changed finally ended up in hysterectomy. $\mathrm{P}$ - value is $<0.05$ shows significant.

In 100 patients, pre-treatment pictorial blood assessment chart score is 319.1 and post treatment pictorial blood assessment chart score is 133.01 , mean reduction in menstrual blood loss is $41.6 \%$ after treated with tranexamic acid. $\mathrm{P}$ - value is $<0.05$ shows significant. 
Table 7: Effect of drug on amount of bleeding.

\begin{tabular}{|llllll|}
\hline Treatment & $\begin{array}{l}\text { Pre treatment } \\
\text { mean PBAC } \\
\text { score }\end{array}$ & $\begin{array}{l}\text { Post treatment } \\
\text { mean PBAC } \\
\text { score }\end{array}$ & P-value & $\begin{array}{l}\text { Mean reduction in } \\
\text { Menstrual blood loss } \\
\text { in present study }(\%)\end{array}$ & $\begin{array}{l}\text { Mean reduction } \\
\text { in MBL in } \\
\text { other studies (\%) }\end{array}$ \\
\hline $\begin{array}{l}\text { Tranexamic acid } \\
\text { (500mg QID) }\end{array}$ & 319.1 & 133.01 & $\begin{array}{l}<0.05 \\
\text { significant }\end{array}$ & $41.6 \%$ & - \\
\hline
\end{tabular}

From the above table it is implied that significant reduction in number of sanitary pad usage was found in patients treated with tranexamic acid. $\mathrm{P}$ value is $<0.05$ shows significant.

Table 8: Effect of drug on duration of bleeding.

\begin{tabular}{|lll|}
\hline Effect of drug & $\begin{array}{l}\text { Duration of bleeding } \\
\text { (mean in days) }\end{array}$ & P-value \\
\hline Before treatment & 9 & $<0.05$ \\
\hline After treatment & 4 & Significant \\
\hline
\end{tabular}

From above table there is little difference in the duration of bleeding between the pre-treatment and post treatment cycle. $\mathrm{P}$ value is $<0.05$ shows significant.

Minor side effects mostly of gastrointestinal origin were seen only in 7 out of 100 patients.

Table 9: Effect of drug on patient satisfaction.

\begin{tabular}{|lll|}
\hline & No of cases & Percentage \\
\hline Satisfied & 68 & $68 \%$ \\
\hline Unsatisfied & 32 & $32 \%$ \\
\hline
\end{tabular}

From the above table, $68 \%$ of the patients are satisfied with the drug. $32 \%$ patients are unsatisfied because of no decrease in blood loss.

From the above table dropouts are only 9\%, 3 patients after first cycle, 6 patients after second cycle because of no effect of drug.

\section{DISCUSSION}

\section{Study group}

Department of obstetrics and gynaecology, Navodaya medical college hospital and research center, Raichur.

\section{Other group}

Department of obstetrics and gynaecology, New York university school of Medicine, New York, USA.

In this all trial (Freeman, Kouides and Lukes) is included involving the efficacy of tranexamic acid for the treatment of heavy uterine bleeding.
In our present trial of efficacy of tranexamic acid for the treatment of heavy uterine bleeding the average percentage of blood loss after treatment with tranexamic acid is $41 \%$, p- value is $<0.05$ (significant) in our group. In trails conducted by Freeman, Kouides and Lukes the mean decrease.

In menstrual blood loss is about $39 \%, 38 \%$ and $40 \%$ respectively, signifying that our study is on par with other studies conducted.

Table 10: Comparison of various studies with decrease menstrual blood loss.

\begin{tabular}{|llll|}
\hline & $\begin{array}{l}\text { Decrease } \\
\text { menstrual } \\
\text { blood loss }\end{array}$ & $\begin{array}{l}\text { Sanitary } \\
\text { pad usage }\end{array}$ & Discontinue \\
\hline $\begin{array}{l}\text { Our } \\
\text { study }\end{array}$ & $41 \%$ & $\begin{array}{l}\text { Significantly } \\
\text { reduced }\end{array}$ & $32 \%$ \\
\hline Freeman & $39 \%$ & $\begin{array}{l}\text { Significantly } \\
\text { reduced }\end{array}$ & $36 \%$ \\
\hline Kouides & $38 \%$ & $\begin{array}{l}\text { Significantly } \\
\text { reduced }\end{array}$ & $43 \%$ \\
\hline Lukes & $40 \%$ & $\begin{array}{l}\text { Significantly } \\
\text { reduced }\end{array}$ & $24 \%$ \\
\hline
\end{tabular}

The other various randomized double cross clinical trails with tranexamic acid showed dose dependent reduction of $35-51 \%$ of menstrual blood loss.

In all four clinical trials (our present study; Freeman; Kouides and Lukes) there is significant reduction in number of sanitary pad usage.

In Kouides and Lukes clinical trial there is no significant difference in duration of bleeding, but in Freeman trail there was significant reduction in number of days and bleeding in successive menstrual cycle.

In Kouides study group there is $43 \%$ discontinuation, $36 \%$ Freeman, $24 \%$ in Lukes and 32\% in our study.

Tranexamic acid is a non-hormonal option that has proven to be an effective treatment for heavy menstrual bleeding. It reduced menstrual blood loss by $38-41 \%$ and it is significantly more effective than placebo, NSAIDS, oral cyclic luteal phase progestins or oral ethamsylate. Tranexamic acid significantly improves the quality of life of women trated for heavy menstrual bleeding. Adverse effects are few and they are mild. 


\section{CONCLUSION}

Tranexamic acid is a non-hormonal and cost effective treatment in menstrual bleeding.

Treatment with tranexamic acid could potentially improve quality of life of women by reducing impairment of social activities and impairment at work and there is substantial improvement in overall well-being. It is also effective treatment for menorrhagia caused by IUCD.

This study and current clinical evidence concludes that size and type of fibroid has significant influence on effect of treatment. Tranexamic acid has been documented and found to have no effect on uterus with adenomyosis and endometrial polyp.

Treatment with tranexamic acid decreased the incidence of hysterectomy avoiding major surgery and its associated complications like anaesthetic complications, intra operative blood loss, blood transfusion reactions, prolonged hospital stay, morbidity and mortality.

Funding: No funding sources

Conflict of interest: None declared

Ethical approval: The study was approved by the Institutional Ethics Committee

\section{REFERENCES}

1. Afkhami-Ardekani M, Rashidi M. Iron status in women with and without gestational diabetes mellitus. Journal of Diabetes and its Complications. 2009;23(3):194-8.

2. Abdulraheem NM. Protection of women's rights under the nigerian plural legal system: faculty of law, university of ilorin; 2010.

3. Tyndall JA, Okoye V, Elumelu F, Dahiru A, Pariya HB. Vitamin $\mathrm{A}$ and iron deficiency in pregnant women, lactating mothers and their infants in Adamawa State, Nigeria: a prospective cohort study. American Journal of Food and Nutrition. 2012;2:14-20.

4. Villar J, Ba'aqeel H, Piaggio G, Lumbiganon P, Belizán JM, Farnot U. WHO antenatal care randomised trial for the evaluation of a new model of routine antenatal care. The Lancet. 2001;357(9268):1551-64.

5. Osgerby J, Gadd T, Wathes D. The effects of maternal nutrition and body condition on placental and foetal growth in the ewe. Placenta. 2003;24(2):236-47.

6. Kalimbira A, Mtimuni B, Chilima D. Maternal knowledge and practices related to anaemia and iron supplementation in rural Malawi: A cross-sectional study. African Journal of Food, Agriculture, Nutrition and Development. 2009;9(1):550-64.

7. Malek A, Sager R, Eckardt KU, Bauer C, Schneider H. Lack of transport of erythropoietin across the human placenta as studied by an in vitro perfusion system. Pflügers Archiv. 1994;427(1-2):157-61.

8. Dinga LA. Factors associated with adherence to Iron/Folate supplementation among pregnant women attending antenatal clinic at Thika District Hospital in Kiambu County, Kenya: University of Nairobi; 2013.

9. Khan KS, Wojdyla D, Say L, Gülmezoglu AM, Van Look PF. WHO analysis of causes of maternal death: a systematic review. The lancet. 2006;367(9516):106674.

10. Jasti S, Siega-Riz AM, Cogswell ME, Hartzema AG, Bentley ME. Pill count adherence to prenatal multivitamin/mineral supplements use among lowincome women. The Journal of nutrition. 2005;135(5):1093-101.

11. Awusi V, Anyanwu E, Okeleke V. Determinants of antenatal care services utilization in Emevor Village, Nigeria. Benin Journal of Postgraduate Medicine. 2009;11(1).

12. Fiedler J, DAgostino A, Sununtnasuk C. A rapid initial assessment of the distribution and consumption of ironâ folic acid tablets through antenatal care in Nepal; 2015.

13. Idowu $\mathrm{O}$, Mafiana $\mathrm{C}$, Dopu $\mathrm{S}$. Anaemia in pregnancy: a survey of pregnant women in Abeokuta, Nigeria. African health sciences. 2005;5(4):295-9.

14. Carpenter CJ. A meta-analysis of the effectiveness of health belief model variables in predicting behavior. Health communication. 2010;25(8):661-9.

15. Ezzati M, Lopez AD, Rodgers A, Vander Hoorn S, Murray CJ. Selected major risk factors and global and regional burden of disease. The Lancet. 2002;360(9343):1347-60.

16. Ugwu E, Olibe A, Obi S, Ugwu A. Determinants of compliance to iron supplementation among pregnant women in Enugu, Southeastern Nigeria. Nigerian journal of clinical practice. 2014;17(5):608-12.

17. Bukar M, Audu B, Sadauki H, Elnafaty A, Mairiga A. Prevalence of iron deficiency and megaloblastic anaemia at booking in a secondary health facility in north eastern Nigeria. Nigerian Medical Journal. 2009;50(2):33.

18. Finlayson K, Downe S. Why do women not use antenatal services in low-and middle-income countries? A meta-synthesis of qualitative studies. 2013;10(1):e1001373.

19. Kennedy GL, Pedro MR, Seghieri C, Nantel G, Brouwer I. Dietary diversity score is a useful indicator of micronutrient intake in non-breast-feeding Filipino children. The Journal of nutrition. 2007;137(2):472-7.

Cite this article as: Hangarg US, Rita D, Reddy RE. To study the role of tranexamic acid in the management of menorrhagia. Int J Reprod Contracept Obstet Gynecol 2016;5:3712-6. 